\title{
Statistics Filenote
}

National Cancer Institute

\section{Source}

National Cancer Institute. Statistics Filenote. NCI Thesaurus. Code C115508.

A notation regarding the decisions, and/or clarification of any information pertaining to the statistics used in a clinical trial. 